\title{
Merenrantaniityt lihakarjan laidunmaina
}

\author{
Marika Niemelä, Sari Jaakola, Arto Huuskonen ja Erkki Joki-Tokola \\ MTT, Pohjois-Pohjanmaan tutkimusasema, 92400 Ruukki, etunimi.sukunimi@mtt.fi
}

Perinnebiotooppien laidunnusohjeiden päivittämiseksi tarvitaan tuoretta kotimaista tutkimustietoa muun muassa nykymuotoisen laidunnuksen kannattavuudesta luonnonlaitumilla. Tässä tutkimuksessa selvitettiin lihakarjan kasvua, merenrantaniittyjen satopotentiaalia ja rehusadon laatua sekä maan kasvuominaisuuksia neljällä Perämeren rantalaitumella vuosina 2003-2005. Lisäksi tarkasteltiin lisärehun vaikutusta vasikoiden kasvuun. Tutkimuksen toteutti MTT Pohjois-Pohjanmaan tutkimusasema osana laajempaa Lumolaidun -hanketta.

Vasikat punnittiin laitumelle laitettaessa ja laidunkauden päättyessä. Rantaniityn kasvuston satoa ja laatua seurattiin aidatuilta koealoilta kerätyistä näytteistä kesäkuussa viikoittain ja kerran heinäkuun lopussa. Kasvustonäytteistä määritettiin kuiva-ainesato, D-arvo, NDF-kuitu-, raakavalkuais- ja kivennäispitoisuudet. Näytteiden keruun yhteydessä määritettiin myös laidunalueen kasvuston korkeus. Vuonna 2005 eri puolilta rantalaidunta otettiin maanäytteet, joista määritettiin maalaji, happamuus, johtoluku sekä eri ravinteiden pitoisuudet.

Merenrantalaitumilla vasikoiden päiväkasvut olivat lehmävasikoilla keskimäärin $0,981 \mathrm{~kg}$ (SD $\pm 0.195, \mathrm{~N}=202)$ ja sonnivasikoilla $1,022 \mathrm{~kg}(\mathrm{SD} \pm 0.246, \mathrm{~N}=215)$ vuorokaudessa. Tuloksissa oli huomattavaa vaihtelua tilojen ja vuosien välillä. Pääsääntöisesti päiväkasvut olivat alhaisempia nurmilaitumiin verrattuna. Lisärehun vaikutusta vasikoiden kasvuun ei pystytty kunnolla tutkimaan pienestä aineistosta ja lukuisista vaihtelutekijöistä johtuen.

Merenrantaniittyjen kuiva-ainesato oli tutkimuksen perusteella hyvin vaihteleva ja maksimissaan $2548 \mathrm{~kg} / \mathrm{ha}$. Satotaso on huomattavasti alhaisempi kuin viljelynurmilla. Rehun laatu oli D-arvon ja NDF-pitoisuuden mukaan samaa tasoa kuin nurmilaitumilla. Raakavalkuaisen ja kivennäisistä fosforin, kaliumin, kalsiumin ja kuparin pitoisuudet olivat rantaniittyjen kasvustossa alhaisemmat, raudan ja mangaanin pitoisuudet puolestaan moninkertaiset verrattuna viljeltyihin nurmiin. Peltomaihin verrattuna merenrantaniittyjen happamassa maaperässä (pH keskimäärin 4,9) on selkeästi vähemmän kalsiumia, kaliumia, fosforia ja kuparia, mutta hyvin runsaasti rikkiä ja natriumia.

Luonnonlaitumilla eläinten kasvutulokseen voi vaikuttaa eri tavoin. Laidunkauden pituus on tärkeää mitoittaa rehun riittävyyden mukaan. Todennäköisesti osa havaituista alhaisista tilakohtaisista kasvutuloksista johtuu liian pitkästä laidunkaudesta. Tutkimustiloilla käytetyt karjarodut olivat pääasiassa isoja rotuja (Simmental, Limousin ja Charolais). Merenrantalaitumet ja luonnonlaitumet yleensäkin soveltuvat oletettavasti parhaiten pienemmille liharoduille (Hereford ja Aberdeen angus), jotka ovat tehokkaampia karkearehujen hyödyntäjiä. Osalla alueista vasikoiden kasvutulosta voitaisiin todennäköisesti parantaa lisäruokinnan avulla.

Sopiva eläintiheys riippuu laitumen ominaisuuksista, mm. laidunnettavan kasvillisuuden määrästä, maaperän kosteudesta, laidunalasta sekä hoidon vaiheesta (kunnostus vai ylläpito) ja tavoitteista. Osalla merenrantaniityistä kunnostusvaiheen jälkeen melko alhaisetkin eläintiheydet, noin 0,5 eläintä/ha, näyttäisivät pitävän kasvillisuuden tavoitellun matalana. Rehun riittävyyden ja eläinten kasvun kannalta eläintiheyttä ei pitäisi nostaa liian korkeaksi.

Asiasanat: lihakarja, emolehmätuotanto, merenrantaniityt, luonnonlaitumet, rehun laatu, kuivaainesato, perinnebiotoopit 


\section{Johdanto}

Suomalainen nautakarjatalous pohjautui 1800-luvulla ja vielä 1900-luvun alkupuolellakin erilaisten niittymaiden ja luonnonlaitumien hyväksikäyttöön. Peltoviljelyn voimistuessa luonnonniityt ja laitumet menettivät lähes täysin merkityksensä rehuntuottajina ja niiden perinteinen käyttö loppui pääosin 1900-luvun puoliväliin mennessä (Vainio 2001). Seurauksena on ollut näiden nk. perinnebiotooppien määrän jyrkkä lasku. Samalla monet näistä elinympäristöistä riippuvat eliölajit ovat harvinaistuneet (Rassi ym. 2001). Vuosina 1991-1998 toteutetun valtakunnallisen kartoituksen perusteella arvokkaita perinnebiotooppeja arvioitiin olevan jäljellä 20000 ha, mikä on vain $1,25 \%$ vuoden 1880 niittyalasta (Vainio ym. 2001).

Vuodesta 1995 alkaen perinnebiotooppien hoitoon on ollut mahdollista saada EU:n maatalouden ympäristötuen erityistukea. Tällöin laiduntamalla tai niittämällä hoidetuille kohteille maksetaan korvausta hoidosta aiheutuvien kustannusten ja tulonmenetysten perusteella. Enimmillään tuki voi olla 420,47 euroa hehtaarilta (Valtioneuvoston asetus 1220/2001). Tukijärjestelmän avulla merkittävä osa merenrantaniityistä on saatu hoidon piiriin (Karja 2004). Pohjois-Pohjanmaalla oli toukokuussa 2004 hoitosopimuksia yhteensä 1917 hehtaarilla merenrantaniityiksi luokitelluilla alueilla (Johanna Helkimo, TE-keskus, 29.11.2005, suullinen tiedonanto). Hoidetut rantaniityt ovat suurelta osin lihakarjalaitumina. Merenrantaniittyjen ja niiden lajiston palauttamisessa on saatu hyviä tuloksia. Esimerkiksi uhanalaisista lajeista ruijanesikko (Primula nutans) ja etelänsuosirri (Calidris alpina schinzii) ovat selvästi hyötyneet hoitotoimista (Mikkola-Roos ja Niikkonen 2005).

Perinnebiotooppien nykyiset laidunnusohjeet (Salminen \& Kekäläinen 2000, Pykälä 2001, Korpilo 2002) perustuvat pitkälti ulkomaisiin julkaisuihin (Alexandersson ym. 1986, Ekstam ja Forshed 1996). Tuoreelle kotimaiselle tutkimustiedolle on siis selkeästi tarvetta hoito-ohjeiden päivittämiseksi viranomaisten ja maatalousyrittäjien tarpeisiin. Hoitomenetelmien luontovaikutusten arvioinnin lisäksi tarvitaan perustietoa eri hoitotoimien, esimerkiksi nykymuotoisen laidunnuksen kannattavuudesta luonnonlaitumilla.

Tässä tutkimuksessa selvitettiin lihakarjan kasvua, merenrantaniittyjen satopotentiaalia ja rehusadon laatua sekä maan kasvuominaisuuksia Perämeren rantalaitumilla vuosina 2003-2005. Lisäksi tarkasteltiin lisärehun vaikutusta vasikoiden kasvuun. Tutkimuksen toteutti MTT Pohjois-Pohjanmaan tutkimusasema osana laajempaa Lumolaidun -hanketta. Tutkimushanke oli osa maatalousluonnon monimuotoisuuden tutkimusohjelmaa (LUMOTTU). Hanketta rahoittivat maa- ja metsätalousministeriö sekä ympäristöministeriö.

\section{Aineisto ja menetelmät}

\section{Laitumet ja eläimet}

Tutkimus suoritettiin vuosina 2003-2005 tilatutkimuksena neljän emolehmätilan (A, B, C, D) vuokraamilla merenrantaniityillä Perämeren rannikolla Lumijoella, Limingassa ja Hailuodossa. Nämä niityt ovat olleet v. 1995-1997 alkaen kyseisten tilojen laidunmaina ja niille on saatu perinnebiotooppien hoitoon tarkoitettua erityistukea. Laiduntava karja on koostunut pääosin risteytysemoista vasikoineen, hiehoista ja 1-5 sonnista (Taulukko 1). Kahdella laitumella vasikoille on annettu erityisluvalla lisärehua. Eläintiheys (aikuisia eläimiä /ha) on vaihdellut seuraavasti: tila A $0,41-0,66$; tila B 0,53-0,61; tila C $0,50-0,62$ ja tila D $0,27-0,37$. Tilalla $D$ eläintiheys on pidetty alhaisena, koska valtaosa laitumesta on heikkotuottoisempaa metsälaidunta.

\section{Karjan seuranta}

Karjan kasvua seurattiin kaikilla tiloilla punnitsemalla vasikat laidunkauden alussa ja laitumelta pois otettaessa. Vasikoiden syntymäajat, rodut ja sukupuolet kopioitiin tilojen nautaeläinkorteista tai määritettiin punnitusten yhteydessä. Kattavat tiedot syntymäajoista saatiin vain tiloilta A ja D. Näillä tiloilla vasikat olivat laitumelle laitettaessa keskimäärin 51-79 vuorokauden ikäisiä, lisäksi joukossa oli yksittäisiä muutaman päivän - parin viikon ikäisiä vasikoita. 
Taulukko 1. Eläinten määrä ym. laiduntiedot Lumolaidun -hankkeen neljällä merenrantalaitumella vuosina 2003-2005. Käytetyt rodut on ilmoitettu vasikoiden isän mukaan $(\mathrm{Li}=$ Limousin, $\mathrm{Si}=\mathrm{Simmental}, \mathrm{Ch}=\mathrm{Charo-}$ lais). *Laidunvuorokausien määrä on ilmoitettu vasikoiden laitumella viettämän ajan perusteella.

\begin{tabular}{|ccccccccc|}
\hline tila & emot & vasikat & hiehot & sonnit & rodut & lisärehu & $\begin{array}{c}\text { laidun- } \\
\text { vrk* }\end{array}$ & $\begin{array}{c}\text { laidunala } \\
\text { ha }\end{array}$ \\
\hline A & $25-40$ & $25-30$ & - & 1 & $\mathrm{Li}, \mathrm{Si}$ & ei & $58-76$ & $53-63$ \\
\hline B & $102-140$ & $50-73$ & $5-52$ & $3-4$ & $\mathrm{Li}, \mathrm{Ch}, \mathrm{Si}$ & kaura & $85-119$ & n. 270 \\
\hline C & 120 & $61-81$ & $0-30$ & $4-5$ & $\mathrm{Li}, \mathrm{Ch}, \mathrm{Si}$ & ei & $78-105$ & n. 250 \\
\hline D & $15-21$ & $13-21$ & - & 1 & $\mathrm{Si}$ & MulliTähkä & $69-102$ & n. 60 \\
\hline
\end{tabular}

\section{Kasvusto- ja maanäytteet}

Rehusadon ja laadun määrittämiseksi jokaiselle laitumelle perustettiin vuosittain yksi noin $10 \mathrm{~m}$ x 20 $\mathrm{m}$ kokoinen aidattu koeala. Sen sijainti vaihtui vuosittain. Koealalta kerättiin kahdeksan $25 \mathrm{~cm} \times 50$ cm laajuista kasvustonäytettä viikoittain kesäkuussa ja kerran heinäkuun lopussa. Näytteet olivat ensimmäisen sadon näytteitä, eli ne otettiin eri kohdista eri keruukerroilla. Lisäksi jokaiselle koealalle tehtiin kesäkuun lopussa kahdeksan puhdistusniittoalaa, joilta leikattiin kuukautta myöhemmin jälkikasvunäytteet.

Kasvustonäytteistä määritettiin kuiva-ainesato ja MTT:n eläinravitsemuksen laboratoriossa näytteistä analysoitiin D-arvo Nousiaisen ym. (2003) kuvaamalla tavalla sekä NDF-kuitu- ja raakavalkuaispitoisuus Ahvenjärven ym. (2000) kuvaamalla tavalla. Vuonna 2003 kasvustonäytteistä analysoitiin myös kivennäisaineiden pitoisuudet spektrofotometrillä (Luh Huang ja Schulte 1999). Kasvillisuuden korkeuden kehitystä seurattiin nurmitikkumittauksin (Virkajärvi 1996) kauimmin laidunnetuilla lohkoilla kasvustonäytteiden keruukertojen yhteydessä. Vuoden 2005 koealoilta kirjattiin ylös vallitsevat kasvilajit peittävyyden perusteella.

Rantalaidunten pintamaasta ( $20 \mathrm{~cm}$ syvyyteen asti) otettiin vuoden 2005 kesäkuun alussa 10 näytettä tilalta $A, 16$ näytettä tilalta $B, 16$ näytettä tilalta $C$ ja 8 näytettä tilalta $D$. Näytteet otettiin eri puolilta laidunta ja kukin näyte koostui noin 8 osanäytteestä. Maa-analyysit teetettiin Suomen Ympäristöpalvelussa. Näytteistä analysoitiin maalaji, happamuus, johtoluku sekä eri ravinteiden pitoisuudet.

\section{Tulokset ja niiden tarkastelu}

\section{Karjan kasvu}

Laidunkauden aikainen päiväkasvu oli koko aineistossa lehmävasikoilla keskimäärin $0,981 \mathrm{~kg}(\mathrm{SD} \pm$ $0.195, \mathrm{~N}=202)$ ja sonnivasikoilla $1,022 \mathrm{~kg}(\mathrm{SD} \pm 0.246, \mathrm{~N}=215)$ vuorokaudessa. Päiväkasvut erosivat tilojen välillä merkitsevästi kaikkina vuosina (Kruskalin-Wallisin $\mathrm{H}=69.5$, $\mathrm{df}=3, \mathrm{p}<0.001$ (v. 2003); $\mathrm{H}=25.0, \mathrm{df}=2, \mathrm{p}<0.001$ (v. 2004); $\mathrm{H}=50.4$, df =3, $\mathrm{p}<0.001$ (v. 2005); Kuva 1). Vuosien väliset erot olivat merkitseviä tiloilla $\mathrm{A}$ ja $\mathrm{D}$ (Kruskalin-Wallisin $\mathrm{H}=37.7, \mathrm{df}=2, \mathrm{p}<0.001$ (tila $\mathrm{A}$ ); $\mathrm{H}=5.9, \mathrm{df}=2, \mathrm{p}=0.053$ (tila $\mathrm{B}$ ); $\mathrm{H}=0.87, \mathrm{df}=2, \mathrm{p}=0.351$ (tila $\mathrm{C}$ ); $\mathrm{H}=7.4, \mathrm{df}=2, \mathrm{p}=0.024$ (tila D)).

Lisäruokintaa harjoittaneilla tiloilla $\mathrm{B}$ ja $\mathrm{D}$ vasikoiden kasvutulokset olivat toisiinsa nähden huomattavan erilaiset (Kuva 1). Tilalla B vasikoiden päiväkasvut olivat pääsääntöisesti alhaisemmat kuin muilla tiloilla. Tilalla D päiväkasvut olivat puolestaan korkeampia tai samalla tasolla muihin tiloihin verrattuna. Oletettavasti kasvuerot johtuivat suurelta osin muista tekijöistä kuin annetusta lisäruokinnasta.

Merenrantalaitumilla vasikoiden päiväkasvut eivät yltäneet yhtä korkealle kuin nurmilaitumilla (vrt. esim. Virkajärvi ym. 1997, Manninen ym. 2000 ja 2005). Kasvut jäivät myös alhaisemmiksi kuin Tohmajärven niitty- ja metsälaitumilla, missä vasikoiden kasvussa ei havaittu eroa luonnon- ja nurmilaidunten välillä (Virkajärvi ym. 1997).

Rantalaitumilla vasikoiden kasvuissa oli paljon vaihtelua niin tilojen sisällä ja kuin välilläkin (Kuva 1). Parhaimmillaan päiväkasvut olivat verrattavissa nurmilaitumilla saatuihin tuloksiin, pääsääntöisesti ne olivat kuitenkin alhaisemmalla tasolla. Havaittua vaihtelua voivat selittää monet eri tekijät, mm. vasikan rotu ja ikä, laidunkauden pituus, laitumen koko suhteessa eläinmäärään sekä alueittain ja vuosittain vaihtelevat laitumen olosuhteet 

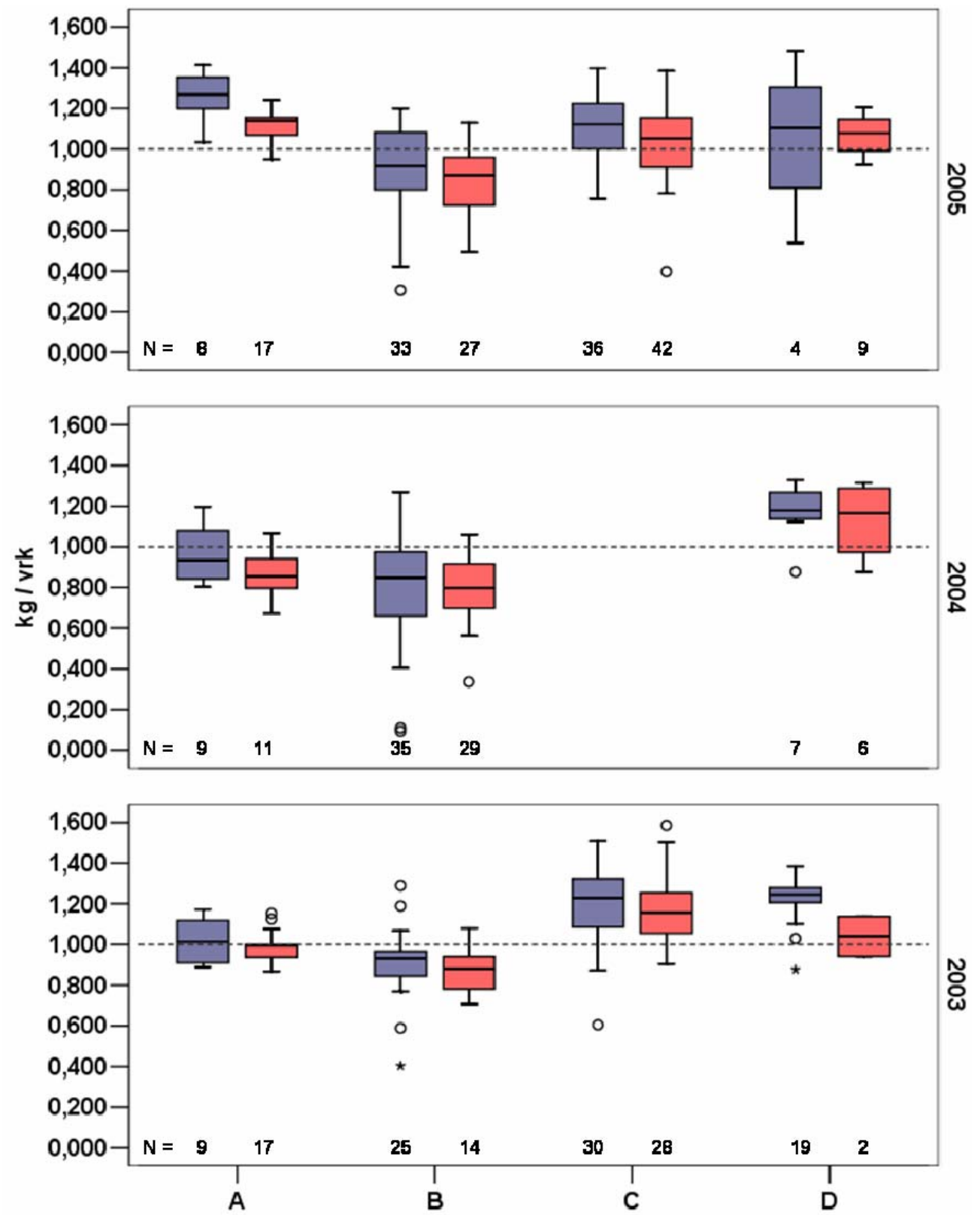

Kuva 1. Vasikoiden (vas. sonnit, oik. lehmät) päiväkasvut (kg/vrk) vuosina 2003-2005 tilojen A, B, C ja D merenrantalaitumilla Pohjois-Pohjanmaalla. Katkoviiva on asetettu helpottamaan vuosien välistä vertailua.

\section{Rantaniittyjen kasvusto}

Merenrantaniittyjen kuiva-ainesadossa oli huomattavaa vaihtelua tilojen välillä (Kuva 2). Suurin mitattu maksimisato $2548 \mathrm{~kg} / \mathrm{ha}$ oli 23.6 .2005 tilalla C sarojen, luhtakastikan ja järviruo'on vallitsemalla koealalla. Pienin maksimisato $1172 \mathrm{~kg} /$ ha havaittiin puolestaan 23.6 .2005 tilan B luhtakastikkavaltaisella koealalla. Rantalaidunten satotaso jää huomattavasti alhaisemmaksi kuin viljellyillä nurmilla. Esimerkiksi MTT:n Pohjois-Pohjanmaan tutkimusasemalla Ruukissa viikoittaiset nurmen satoarviot olivat vuonna 2005 kesäkuun 7. päivästä alkaen 2200, 3600, 5300 ja 6500 kg kuiva-ainetta hehtaarilla (Artturi 2005). 


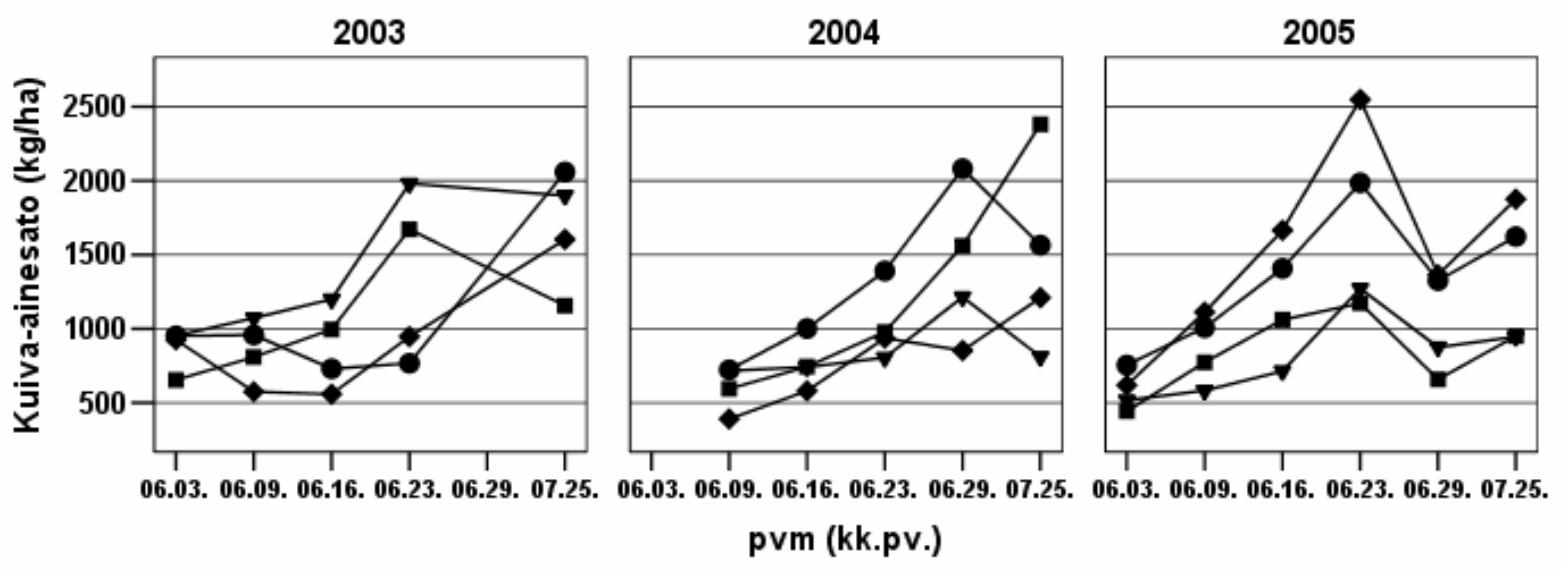

Kuva 2. Merenrantaniittyjen keskimääräinen kuiva-ainesato vuosina 2003-2005 neljällä rantalaitumella PohjoisPohjanmaan rannikolla. Tila $\mathrm{A}=\boldsymbol{\nabla}$, tila $\mathrm{B}=\mathbf{\boldsymbol { a }}$, tila $\mathrm{C}=\bullet$ ja tila $\mathrm{D}=\bullet$.

Rantaniittyjen kasvuston D-arvo oli kesäkuussa verrattavissa nurmilaitumiin. Esimerkiksi kesäkuun puolivälissä kasvuston D-arvo vaihteli $71-76 \%$ välillä, poikkeuksena tilan A alhainen D-arvo (64\%) vuonna 2003 (Kuva 3). Vastaavan ajankohdan D-arvo viljellyllä nurmella oli 73\% vuonna 2005 MTT:1lä Ruukissa (Artturi 2005).
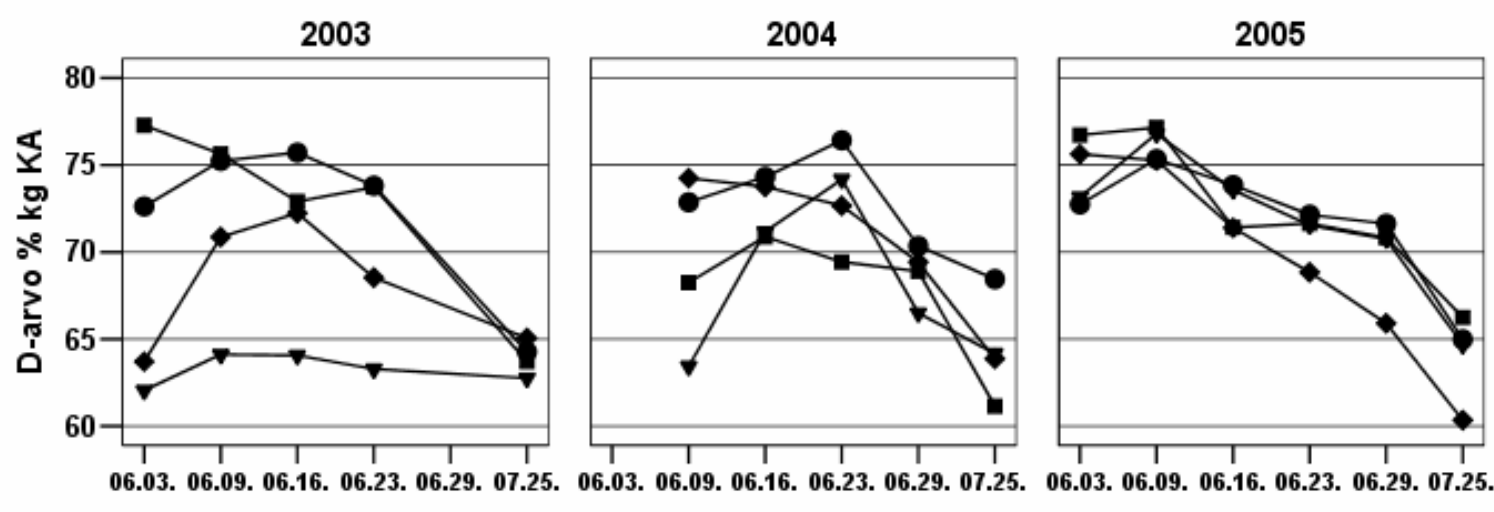

$$
\text { pvm (kk.pv.) }
$$

Kuva 3. Merenrantaniittyjen kasvuston D-arvon kehitys vuosina 2003-2005 neljällä merenrantalaitumella Pohjois-Pohjanmaan rannikolla. Tila $\mathrm{A}=\boldsymbol{\nabla}$, tila $\mathrm{B}=\mathbf{\boldsymbol { a }}$, tila $\mathrm{C}=\bullet$ ja tila $\mathrm{D}=\bullet$.

Raakavalkuaispitoisuuksien vaihteluväli merenrantalaitumilla oli kaikki vuodet mukaan lukien kesäkuun 9. pv $12,3-17,9 \%$, 16. pv $11,3-16,5 \%$, 23. pv 9,3-16,8\% ja 29 . pv 9,6-14,9\% /kg KA. Havaitut raakavalkuaispitoisuudet olivat etenkin kesäkuun alkupuolella alhaisemmat kuin esimerkiksi vuonna 2005 Ruukissa MTT:n nurmilla havaitut: 7. pv 21,5\%, 13. pv 17,7\%, 20 pv. 15,5\% ja 27. pv 10,2\% / kg KA (Artturi 2005).

Kasvuston NDF-kuitupitoisuus nousi merenrantaniityillä kesäkuun aikana seuraavasti: 9. pv $50,2 \%, 16$. pv $53,4 \%, 23$. pv 55,4\% ja 29. pv 58,8\% $/ \mathrm{kg} \mathrm{KA}$, luvut ovat tilojen ja vuosien yli laskettuja keskiarvoja. Kuitupitoisuuden nousu oli samaa luokkaa kuin MTT:n nurmiviljelyksillä Ruukissa vuonna 2005; siellä NDF oli kesäkuun 7. ja 27. päivinä 45,7 ja 61,0\% /kg KA.

Verrattuna nurmilaitumiin (MTT 2004) rantaniittyjen kasvuston kivennäispitoisuudet ovat alhaiset fosforin $(2,4 \mathrm{~g} / \mathrm{kg})$, kaliumin $(18,4 \mathrm{~g} / \mathrm{kg})$, kalsiumin $(3,5 \mathrm{~g} / \mathrm{kg})$ ja kuparin $(6,4 \mathrm{mg} / \mathrm{kg})$ suhteen, suluissa kesäkuun 2003 keskiarvot eri mittauskertojen ja tilojen yli laskettuna. Rantaniittyjen kasvustossa on sen sijaan noin 50-kertaisesti natriumia $(4,9 \mathrm{~g} / \mathrm{kg})$, yhdeksänkertaisesti rautaa $(1281 \mathrm{mg} / \mathrm{kg}) \mathrm{ja}$ viisinkertaisesti mangaania $(250 \mathrm{mg} / \mathrm{kg})$ nurmilaitumiin verrattuna. Magnesiumin, rikin ja sinkin pitoisuudet ovat samalla tai hieman korkeammalla tasolla kuin nurmilaitumilla. 
Puhdistusniitto kesäkuun lopussa nosti jonkin verran rehun laatua rantaniityillä heinäkuun lopun jälkikasvussa. Voimakkaimmin puhdistusniitto nosti raakavalkuaisen pitoisuutta, erityisesti vuonna 2005, jolloin se nousi samalle tasolle tai jopa korkeammaksi kuin alkukesällä. Sen sijaan D-arvo nousi korkeintaan kesäkuun lopun tilannetta vastaavalle tasolle. Puhdistusniittoa seurannut jälkikasvusato jäi alhaiseksi ollen pääsääntöisesti noin $500 \mathrm{~kg} / \mathrm{ha}$ heinäkuun lopulla.

Kasvuston keskimääräinen korkeus heinäkuun lopulla vaihteli seuraavasti (vuonna 2003 ja 2005): tila A 7,3-8,6 cm, tila B $14,0-12,6 \mathrm{~cm}$, tila C $12,1-30,7 \mathrm{~cm}$ ja tila $\mathrm{D} 7,1-11,4 \mathrm{~cm}$.

\section{Maan ominaisuudet}

Merenrantaniittyjen maa osoittautui happamaksi ( $\mathrm{pH}$ 4,9 $\pm 0,6 \mathrm{SD}$ ) ja runsaasti liukoisia suoloja sisältäväksi (johtoluku 14,2 $\pm 5,0 \mathrm{SD}$ ). Verrattuna peltomaiden keskimääräisiin arvoihin (MäkeläKurttio ym. 2002) rantaniittyjen maaperässä on selkeästi vähemmän kalsiumia (273 mg $\mathrm{l}^{-1} \pm 105 \mathrm{SD}$ ), kaliumia $\left(67 \mathrm{mg} \mathrm{l}^{-1} \pm 29 \mathrm{SD}\right)$, fosforia $\left(3,9 \mathrm{mg} \mathrm{l}^{-1} \pm 3,9 \mathrm{SD}\right)$ ja kuparia $\left(1,3 \mathrm{mg} \mathrm{l}^{-1} \pm 0,8 \mathrm{SD}\right)$, mutta hyvin runsaasti rikkiä (360 $\left.\mathrm{mg}^{-1} \pm 185 \mathrm{SD}\right)$ ja natriumia $\left(557 \mathrm{mg} \mathrm{l}^{-1} \pm 245 \mathrm{SD}\right)$. Magnesiumin $(211$

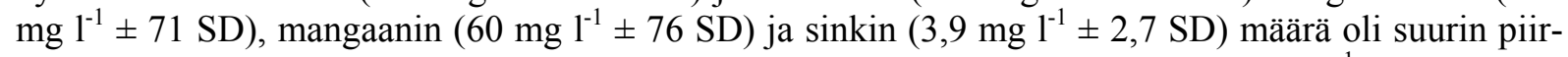
tein samaa tasoa kuin peltomaassa. Liukoista typpeä oli ammonium-muodossa $3,3 \mathrm{mg} \mathrm{l}^{-1}( \pm 1,9 \mathrm{SD}) \mathrm{ja}$ nitraatti-muodossa $0,4 \mathrm{mg} \mathrm{l}^{-1}( \pm 0,1 \mathrm{SD})$. Tutkittujen rantaniittyjen pintamaa koostui vähämultaisesta karkeasta hiedasta tai multavasta, osin savisesta hienosta hiedasta.

\section{Johtopäätökset}

Merenrantaniittyjen sato oli huomattavasti alhaisempi kuin viljellyillä nurmilaitumilla. Satomäärissä oli myös runsaasti vaihtelua. Rehun laatu oli kesäkuussa D-arvon ja NDF-pitoisuuden mukaan samaa tasoa kuin nurmilaitumilla. Raakavalkuaispitoisuudet olivat rantalaidunten kasvustossa alhaisemmat etenkin kesäkuun alussa. Kivennäisaineista fosforin, kaliumin, kalsiumin ja kuparin pitoisuudet olivat rantaniittyjen kasvustossa alhaisemmat, natriumin, raudan ja mangaanin pitoisuudet puolestaan moninkertaiset verrattuna viljeltyihin nurmiin.

Rehun sato- ja laatuhavainnot aidatuilta koealoilta kertovat laiduntamattoman rantaniityn tilanteen mittausajankohtina. Todellisella laidunalueella rehun laatu on jonkin verran parempaa johtuen laidunnuksen kasvustoa nuorentavasta vaikutuksesta, mutta toisaalta saatavilla olevan rehun määrä on havaittua maksimisatoa alhaisempi.

Merenrantalaidunten suuret laidunalat kompensoivat osittain alhaista pinta-alakohtaista satoa. Toisaalta eläinten on myös laidunnettava laajemmalla alueella ja käytettävä enemmän aikaa laiduntamiseen. Tämä todennäköisesti johtaa alentuneeseen maidontuotantoon emolehmillä ja vaikuttaa myös vasikoiden kasvuun. Merenrantalaitumilla vasikoiden päiväkasvut olivatkin pääsääntöisesti alhaisempia verrattuna nurmilaitumilla havaittuihin kasvuihin. Lisärehun vaikutusta vasikoiden kasvuun ei tässä tutkimuksessa pystytty kunnolla havainnoimaan pienestä aineistosta ja lukuisista vaihtelutekijöistä johtuen.

Luonnonlaitumillakin eläinten kasvutulokseen voi vaikuttaa eri tavoin. Laidunkauden pituus on tärkeää mitoittaa rehun riittävyyden mukaan. Todennäköisesti osa havaituista alhaisista tilakohtaisista kasvutuloksista johtuu liian pitkästä laidunkaudesta. Tutkimustiloilla käytetyt karjarodut olivat pääasiassa isoja rotuja (Simmental, Limousin ja Charolais). Voisi kuitenkin olettaa, että merenrantalaitumet ja luonnonlaitumet yleensäkin soveltuisivat parhaiten pienemmille liharoduille (Hereford ja Aberdeen angus), jotka ovat tehokkaampia karkearehujen hyödyntäjiä. Osalla alueista vasikoiden kasvutulosta voitaisiin todennäköisesti parantaa lisäruokinnan avulla.

Sopiva eläintiheys riippuu laitumen ominaisuuksista, mm. laidunnettavan kasvillisuuden määrästä, maaperän kosteudesta, laidunalasta sekä hoidon vaiheesta (kunnostus vai ylläpito) ja tavoitteista. Osalla merenrantaniityistä kunnostusvaiheen jälkeen melko alhaisetkin laidunnuspaineet, noin 0,5 eläintä/ha, näyttäisivät pitävän kasvillisuuden tavoitellun matalana. Yhdellä kohteista (tila A, vuosi 2003) jo 0,66 eläintä/ha laidunnuspaine aiheutti huomattavaa laitumen kulumista tietyissä osissa laidunta. Rehun riittävyyden ja eläinten kasvun kannalta eläintiheyttä ei pitäisi nostaa liian korkeaksi. 


\section{Kirjallisuus}

Ahvenjärvi, S., Vanhatalo, A., Huhtanen, P. \& Varvikko, T. 2000. Determination of reticulo-rumen and stomach digestion in lactating cows by omasal canal and duodenal sampling. British J. Nutr. 83: 67-77.

Alexandersson, H., Ekstam, U. \& Forshed, N. 1986: Stränder vid fågelsjöar. Om fuktängar, madder och vassar i odlingslandskapet. LTs förlag. Stocholm. $112 \mathrm{~s}$.

Artturi 2005. Nurminäytteiden analyysitulokset, Pohjois-Pohjanmaa [verkkojulkaisu]. MTT (Eläinravitsemus ja Tietopalvelut) sekä Valio Oy/Alkutuotanto. Viitattu 30.11.2005. Saatavissa: http://artturi.agronet.fi/scripts/Alueraportti.exe/alue?Haku=17.

Ekstam, U. \& Forshed, N. 1996. Äldre fodermarker. Naturvårdsverket, Värnamo, 135 s.

Karja, M. 2004. Perinnebiotooppien hoidon, luonnon monimuotoisuuden edistämisen ja maiseman kehittämisen ja hoidon toteutuminen 1995-2003. Maa- ja metsätalousministeriön raportti 28.5.2004. 146 s. + liitteet.

Korpilo, B. 2002. Eläimet luonnon- ja maisemanhoitajina. Maa- ja metsätalousministeriö, Painorauma, $23 \mathrm{~s}$.

Luh Huang, C.-Y. \& E.E. Schulte. 1985. Digestion of plant tissue for analysis by ICP emission spectrometry. Communications in soil science and plant analysis 16: 943-958.

Manninen, M., Aronen, I. \& Huhta, H. 2000. Effect of feeding level and diet type on the performance of crossbred suckler cows and their calves. Agric. Food Sci. Finland 9: 3-16.

Manninen, M., Virkajärvi, P. \& Jauhiainen, L. 2005. Effect of whole-crop barley and oat silages on the performance of mature suckler cows and their progeny in outdoor winter feeding. Anim. Feed Sci. Technol. 121: 227-242.

Mikkola-Roos, M. \& Niikkonen, T. (toim.) 2005. Kosteikkojen kunnostuksen ja hoidon parhaat käytännöt kuudella Life-kohteella Suomessa - Life CO-OP -hankkeen tulokset. Metsähallituksen luonnonsuojelujulkaisuja. Sarja A 149, $120 \mathrm{~s}$.

MTT 2004. Rehutaulukot ja ruokintasuositukset [verkkojulkaisu]. Jokioinen: Maa- ja elintarviketalouden tutkimuskeskus. Julkaistu 30.6.2004, [viitattu 30.11.2005]. Saatavissa: http://www.agronet.fi/rehutaulukot/. URN:NBN:fi-fe20041449.

Mäkelä-Kurtto, R., Sippola, J. \& Grek, K. 2002. Peltomaiden viljavuus ja helppoliukoiset raskasmetallit. Teoksessa: Uusitalo, R. \& Salo, R. (toim.) Tutkittu maa - turvalliset elintarvikkeet. Viljavuustutkimus 50 vuotta -juhlaseminaari Jokioinen 24.9.2002. Maa- ja elintarviketalous 13: 30-46.

Nousiainen, J., Rinne, M., Hellämäki, M. \& Huhtanen, P. 2003. Prediction of the digestibility of primary growth and regrowth grass silages from chemical composition, pepsin-cellulase solubility and indigestible cell wall content. Anim. Feed Sci. Technol. 110: 61-74.

Pykälä, J. 2001. Perinteinen karjatalous luonnon monimuotoisuuden ylläpitäjänä. Suomen ympäristö 495 . Vammala. $205 \mathrm{~s}$.

Rassi, P., Alanen, A., Kanerva, T. \& Mannerkoski, I. (toim.) 2001: Suomen lajien uhanalaisuus 2000. Ympäristöministeriö \& Suomen ympäristökeskus, Helsinki.

Salminen, P. \& Kekäläinen, H. (toim.) 2000. Perinnebiotooppien hoito Suomessa. Perinnemaisemien hoitotyöryhmän mietintö. Suomen ympäristö 443, $162 \mathrm{~s}$.

Vainio, M., Kekäläinen, H., Alanen, A. \& Pykälä, J. 2001. Suomen perinnebiotoopit. Perinnemaisemprojektin valtakunnallinen loppuraportti. Suomen ympäristö 527, $165 \mathrm{~s}$.

Valtioneuvoston asetus 1220/2001. Valtioneuvoston asetus luonnonhaittakorvauksesta ja maatalouden ympäristötuesta annetun valtioneuvoston asetuksen muuttamisesta.

Virkajärvi, P. 1996. Laidunnurmen kuiva-ainemassan epäsuora määrittäminen. In: Kotieläintieteen päivät 1996: Kotieläintiede 90 vuotta -juhlaseminaari. Maaseutukeskusten Liiton julkaisuja 905: 125-127.

Virkajärvi, P, Tuupanen, R., Hokkanen, T. \& Huhta, H. 1997. Emolehmät niitty- ja metsälaidunten hyödyntäjinä ja säilyttäjinä. Teoksessa: Salo, R. (toim.), Maa kasvun antaa. Maatalouden tutkimus- ja tuotantopäivät, Jokioinen 5.-7.8.1997. Maatalouden tutkimuskeskuksen julkaisuja. Sarja A 27: 91-96. 